\title{
ETIKA DALAM MASYARAKAT MADANI (PERSPEKTIF DAKWAH ISLAM)
}

\author{
Oleh: Misrah
}

\begin{abstract}
Abstrak
One of the values consisting in public model madani is ethics. Ethics is universal element in developing public madani, because ethics relate to attitude, habit, order, actions and morale having the character of correctness about goodness and badness.
\end{abstract}

Kata Kunci: Madani, Masyarakat Madani, Etika madani

\section{Pendahuluan}

Wacana tentang "masyarakat Madani" dewasa ini sudah semakin terlupakan. Berbeda dengan awal tahun 1990-an bahwa banyak seminar dan tulisan, baik buku maupun artikel di majalah dan koran yang mengacu pada konsep dan gagasan masyarakat madani. Istilah itu sendiri dari beberapa literatur ditemukan beberapa persamaan dan perbedaan dengan istilah lainnya-seperti civil society, masyarakat sipil dan sebagainya, ${ }^{1}$ yang semuanya mengacu kepada tujuan masyarakat yang berperadaban dalam arti luas.

${ }^{1}$ Mansur Fakih, Masyarakat Sipil untuk Transformasi Sosial: Pergolakan Ideologi di Dunia LSM Indonesia, Pustaka Pelajar, Yogyakarta, 1996. Ernest Gellner, Membangun Masyarakat Sipil : Prasyarat Menuju Kebebasan, Mizan, Bandung, 1995 dan Naskah Pidato Anwar Ibrahim, Islam dan Pembentukan Masyarakat Madani, dalam Buku Aswab Mahasin et.al. (ed), Ruh Islam dalam Budaya Bangsa: Wacana antar Agama dan Bangsa, Yayasan Festival Istiqlal, Jakarta, 1996. 
Bukanlah suatu kebetulan bahwa wujud nyata masyarakat madani itu untuk pertama kalinya dalam sejarah umat Islam merupakan hasil usaha utusan Tuhan untuk akhir zaman, Nabi Muhammad Saw, sesampainya di kota Hijrah, yaitu Yasrib (Yunani: Yethroba), beliau ganti nama kota itu menjadi Madinah. Dengan tindakan itu, Nabi Muhammad saw. telah merintis dan memberi teladan kepada umat manusia dalam membangun masyarakat madani, yaitu masyarakat yang berperadaban (ber-madaniah) karena tunduk patuh (dana-yadinu) kepada ajaran kepatuhan (din) yang dinyatakan dalam supremasi hukum dalam peraturan. ${ }^{2}$

Masyarakat madani pada hakikatnya adalah reformasi total terhadap masyarakat yang tidak mengenal hukum (lawless) Arab Jahiliyah. ${ }^{3}$ Madinah dapat mencapai negara yang adil dan sejahtera berkat pondasi nilai-nilai Madani yang dibangun oleh Nabi saw. Namun mengapa umat Islam setelah itu senantiasa gagal membangun fondasi masyarakat Madani dalam sendi kehidupannya dewasa ini, tentu banyak analisis yang dapat dikemukakan untuk menjawabnya.

Pada pakar ilmu-ilmu sosial dan politik pada umumnya melihat kegagalan disebabkan karena minusnya partisipasi masyarakat dalam proses pembangunan, hal ini sebagai penyebab internal. Secara eksternal, proses percepatan globalisasi budaya yang tidak mampu direspon secara berimbang akan menjangkitkan penyakit cultural shock (kekagetan budaya) secara kolektif yang berakibat pada gagalnya anggota masyarakat menemukan pijakan ideologis yang kuat. Dalam masyarakat yang demikian tentu saja etika menjadi sikap hidup yang langka. Baik secara politis maupun secara kultural umumnya anggota masyarakat tidak memiliki etika dan ketidakjelasan jati diri.

Sedangkan bagaimana sistem etika (moral) yang juga menjadi ciriciri utama masyarakat madani semacam itu bisa dibentuk, perlu kita menyadari eksistensi kemanusiaan sebagai makhluk Tuhan yang memiliki kebebasan

${ }^{2}$ Naquib Al-Attas, Masyarakat Madani, Wajah Indonesia tahun 2020 di Harian Republika, 15 September 1998, h. 2.

${ }^{3}$ Berkaitan dengan ini, Alquran menggambarkan bahwa orang-orang Arab Badui (nomad) adalah lebih kafir dan munafik, dalam arti sangat potensial untuk tidak tunduk kepada hukum dan peraturan. Maka patut diperhatikan bahwa salah satu makna kekafiran ialah sikap tidak patuh kepada hukum dan peraturan (lawlessness). 
berkehendak dan berbuat (free will dan free act) serta bertanggung jawab atas segala kehendak dan perbuatannya itu. Untuk dapat mengaktualisasikannya, diperlukan rumusan etika Madani sebagaimana yang telah diterapkan Nabi saw. dan sahabatnya dahulu.

\section{Masyarakat Madani}

Masyarakat madani adalah "lukisan ideal" Islam masa lalu yang dikenal dengan istilah masyarakat Salaf, ${ }^{4}$ yang telah melahirkan sebuah negara atau state, yang sudah sangat maju dibandingkan dengan negaranegara pada masanya atau yang pernah ada dalam sejarah sebelumnya. Ini digambarkan oleh Robert N. Bellah, sosiolog Amerika terkemuka:

Tidak lagi dapat dipersoalkan bahwa di bawah Nabi Muhammad masyarakat Arab telah membuat lompatan jauh ke depan dalam kecanggihan sosial dan kapasitas politik. Tatkala struktur yang telah terbentuk dikembangkan oleh para khalifah pertama untuk menyediakan prinsip penyusunan suatu imperium dunia, hasilnya sesuatu masa dan tempat yang sangat modern. Ia modern dalam hal tingginya tingkat komitmen, keterlibatan dan partisipasi yang diharapkan dari kalangan rakyat jelata sebagai anggota masyarakat. la modern dalam hal keterbukaan kepemim-pinannya untuk dinilai, kemampuan mereka menurut landasan-landasan universalitas dan dilambangkan dalam upaya melembagakan kepemimpinan yang tidak bersifat turun temurun. Meskipun pada saat-saat yang paling dini muncul hambatan-hambatan tertentu yang menghalangi masyarakat untuk sepenuhnya melaksanakan model yang dicontohkan Nabi itu. Namun mereka sudah sedemikian cukup dekatnya menampilkan suatu model bagi susunan masyarakat modern yang lebih baik dari yang dapat dibayangkan. Upaya orang-orang Muslim modern untuk melukiskan masyarakat dini tersebut sebagai contoh yang sesungguhnya terlihat dari nilai-nilai nasionalisme, partisipatif dan egaliter yang sama sekali bukanlah suatu pembentukan ideologis yang tidak historis. Eksperimen itu terlalu modern pada masa itu. ${ }^{5}$

${ }^{4}$ Nurcholish Madjid, Cita-cita Politik Islam Era Reformasi, Paramadina, Jakarta, 1999, h. 92-93.

5Ibid., h. 32,33 dan 35. 
Masyarakat salaf ini, menurut Nurcholish dalam bahasa modern sekarang menjadi generasi yang menerapkan secara empiris prinsip normatif Islam tentang egalitarianisme, demokrasi, partisipasi dan keadilan sosial sebagaimana dikatakan oleh Bellah di atas. Masyarakat ini telah menyajikan kepada umat manusia, sebuah gambaran tatanan sosial politik yang telah mengenal kehidupan berkonstitusi, di bawah naungan konstitusi yang dikenal dengan sebutan Mitsaq al-Madinah (Piagam Madinah). ${ }^{6}$

Dalam kaitan ini istilah masyarakat madani sebenarnya hanya salah satu di antara beberapa istilah lain yang sering kali digunakan orang untuk menyebut masyarakat sejahtera, padanan katanya adalah civil society. Di samping masyarakat madani, padanan kata lainnya yang sering di gunakan adalah masyarakat warga atau kewargaan, masyarakat sipil, masyarakat beradab atau masyarakat berbudaya ${ }^{7}$. Istilah civil society juga identik dengan "masyarakat berbudaya" (civil society). Lawannya, adalah "masyarakat liar" (savage society) ${ }^{8}$.

Pemahaman yang melatari arti ini, untuk memudahkan orang menarik perbandingan dimana kata yang pertama merujuk pada masyarakat yang saling menghargai nilai-nilai sosial kemanusiaan (termasuk dalam kehidupan politik), sedangkan kata yang kedua jika dapat diberikan penjelasan menurut pemikiran Thomas Hobbes, bermakna identik dengan gambaran masyarakat tahap "keadaan alami" (state of nature) yang tanpa hukum sebelum lahirnya negara dimana setiap manusia merupakan serigala bagi sesamanya (homo homini lupus). Eksistensi civil society sebagai sebuah abstraksi sosial dihadapkan secara kontradiktif dengan masyarakat alami (natural society). ${ }^{9}$

Masyarakat modern masih ada yang mendukung ciri-ciri tribalisme, yang cenderung memberikan penghargaan berdasarkan prestise (keturunan, kesukuan, ras dan lain-lain), bukan berdasarkan prestasi. Begitu juga sebagian masyarakat ditemukan mendukung sistem dinasti geneologis (sistem dinasti

${ }^{6}$ Oleh banyak ahli sejarah klasik Islam, seperti Ibn Ishaq (w. $152 \mathrm{H}$ ) dan Muhammad Ibn Hisyam (w. 218 H) telah mendokumentasikan Piagam Madinah. h. 3

${ }^{7}$ Adi Suryadi Culla, Masyarakat Madani, RajaGrafindo Persada, Jakarta, 1999,

${ }^{8}$ Lih, Abdul Aziz Thaha, Islam dan Negara dalam Politik Orde Baru, Gema Insani Press, Jakarta, 1996.

${ }^{9}$ Culla, op.cit., h. 5 
keturunan). Sistem dinasti geneologis itu tidak dikenal dalam ajaran Islam. Sebab bila sistem tersebut (geneologis) terwujud, akan melahirkan perbedaan antara "orang-orang atas" dan "orang-orang bawah" dan perbedaan itu akan menyebabkan kejahatan yang dilakukan "orang-orang atas" dibiarkan, tetapi bila kejahatan itu di lakukan oleh "orang-orang bawah" dihukum. Hal inilah suatu sistem yang menjadi kendala terlaksananya keadilan yang sesungguhnya.

Berdasarkan itu pulalah perlunya manusia kembali membangun suatu "masyarakat madani" yang pernah dibangun oleh Nabi saw, dimana ketika Nabi berhijrah serta hidup mapan di kota tempat hijrahnya itu, Nabi segera merubah nama Yasrib menjadi Al-Madinah. Secara konvensional, perkataan "madinah" memang diartikan sebagai "kota". Tetapi secara ilmu kebahasan perkataan itu mengandung makna "peradaban". Karena itu tindakan Nabi mengubah nama Yasrib menjadi "madinah" pada hakikatnya adalah sebuah pernyataan niat, atau proklamasi, bahwa beliau bersama para pendukungnya yang terdiri dari kaum Muhajirin dan kaum Anshar hendak mendirikan dan membangun masyarakat beradab. ${ }^{10}$

Membangun masyarakat madani atau masyarakat yang berperadaban itulah yang dilakukan Nabi selama sepuluh tahun di Madinah, di mana masyarakat demokratis, masyarakat yang adil, terbuka, dengan landasan taqwa kepada Allah swt dan taat kepada ajaran-ajaran-Nya. Masyarakat tersebut bercirikan "egalitarianisme" yakni penghargaan kepada orang berdasarkan prestasi (bukan prestise), tidak mengenal sistem dinasti geneologis (keturunan). ${ }^{11}$

Masyarakat Madinah didiami oleh bermacam golongan suku bangsa Arab dan Yahudi yang menganut agama dan keyakinan yang berbeda. Corak masyarakatnya yang majemuk ini bertambah kompleks sejak sebagian penduduknya memeluk Islam dan setelah Nabi Muhammad saw bersama kaum muslim Mekah hijrah ke kota itu.

Para ahli berbeda pendapat dalam merumuskan golongan-golongan penduduk yang terdapat di Madinah pascahijrah. Emile Dermenghem

${ }^{10}$ Nurcholish Madjid, Menuju Masyarakat Madani, dalam Ulumul Qur'an. No.2/vii/1996, h. 51

${ }^{11}$ Ibid., h.52 
membagi penduduk Madinah kedalam empat golongan, yaitu Muhajirin, orang-orang Islam imigran dari Mekah; Anshar, orang-orang Islam Madinah; kaum munafik, suku-suku pagan; dan Yahudi. ${ }^{12}$

A.G. Bouquet, ${ }^{13}$ juga menyebut tiga golongan tanpa menyebutkan kaum Yahudi, yaitu Muhajirin, Anshar, dan munafik. Alasan yang ia kemukakan sehingga tidak dimasukkannya orang-orang Yahudi sebagai bagian dari penduduk Madinah, ialah karena menurutnya orang-orang

Yahudi maupun Kristen menganggap risalah Nabi Muhammad tidak baru dan orisinal dan beliau bukan pelopor agama yang murni. Kelihatannya pandangan umat Yahudi dan Kristen tentang posisi Nabi Muhammad tersebut tidak bisa dijadikan alasan untuk tidak menyebut kaum Yahudi bagian dari penduduk Madinah. Sebab kalau merujuk kepada teks Piagam Madinah disebut dengan jelas beberapa golongan Yahudi sebagai bagian dari orang-orang mukmin.

Sedangkan Muhammad Khalid hanya menggolongkan penduduk Madinah ke dalam dua golongan saja, yaitu kaum muslimin Muhajirin dan Anshar dan kaum Yahudi. ${ }^{14}$ Demikian juga 'Abd al-Muta'al al-Shu'adi mengelompokkannya ke dalam dua golongan. Tapi ia melihatnya dari segi kebangsaannya, yaitu bangsa Arab yang terdiri dari berbagai suku. ${ }^{15}$

Kitab suci Alquran juga menyinggung tentang penduduk Madinah yang terdiri dari berbagai kelompok keyakinan. Dalam surat al-Taubat/9 ayat 100 dan 117 disebut kaum Muhajirin dan Anshar, dan pada ayat 101 disebut dengan jelas adanya golongan munafik di sekitar mereka. Sedangkan golongan Yahudi, Nasrani, dan musyrik baik yang tinggal di Madinah maupun di sekitarnya disebut dalam surat al-Ma'idat/5 ayat 82. ${ }^{16}$

${ }^{12}$ Zainal Abidin Ahmad, Piagam Nabi Muhammad Saw. Konstitusi Negara Tertulis yang Pertama di Dunia, Bulan Bintang, Jakarta, 1973, h.93.

${ }^{13}$ Zainal Abidin Ahmad, op.cit., h. 94-95.

${ }^{14}$ Muhammad Khalid, Khatam al-Nabiyyin, al-Qahirat, t. th., h.116.

${ }^{15}$ Zainal Abidin Ahmad, op.cit., h. 95

${ }^{16}$ Ayat-ayat tersebut menunjukkan bahwa Alquran dapat dijadikan sumber sejarah karena informasinya terbukti dalam kenyataan histories. 


\section{Peran Etika dalam Membangun Masyarakat Madani}

Uraian sebelumnya menunjukkan bahwa heterogenitas penduduk Madinah adalah dalam hal etnis dan bangsa, asal daerah, ekonomi, agama dan keyakinan serta adat kebiasaan. Kondisi ini menyebabkan tiap golongan memiliki cara berpikir dan bertindak sendiri dalam mewujudkan kepentingannya sesuai dengan filosofis hidupnya yang dipengaruhi oleh keyakinan yang dianutnya, kulturnya dan tuntutan situasi. Ditambah pula manusia sebagai makhluk sosial dan makhluk etika yang mempunyai "dua sifat yang bertentangan satu sama lain; di satu pihak dia ingin kerja sama, di pihak lain dia cenderung untuk bersaing dengan sesama manusia". ${ }^{17}$

Faktor-faktor tersebut mengakibatkan mudahnya timbul konflik di antara mereka. Sebab, masyarakat yang terdiri dari berbagai golongan dan mempunyai perbedaan kepentingan yang tajam dalam bidang sosial, ekonomi, politik, dan sebagainya cenderung ingin saling menghancurkan. ${ }^{18}$

Teori tersebut telah terbukti pada kelompok-kelompok sosial di Madinah sebelum Islam yang selalu bermusuhan dan berperang sebagai telah diuraikan di atas. Sikap kelompok-kelompok tersebut dalam meng-hadapi kedatangan Nabi dan pengikutnya di kota itu; ada yang menyam-butnya dengan gembira dan ada pula yang tidak senang, seperti Abu 'Amir dan 'Abdullah bin Ubay, pemimpin suku Aus dan Khazraj, sangat kecewa atas kehadiran Nabi dan pengikutnya. Sebab, hal itu akan mementahkan rencana mereka untuk menobatkan 'Abdullah bin Ubay menjadi raja Madinah. Dalam pada itu kaum Yahudi sebagai raja-raja dagang juga ingin berkuasa atas kota Madinah. ${ }^{19}$ Kondisi masyarakat demikian, menurut Watt, menghendaki munculnya orang kuat yang dapat menguasai sebagian atau seluruh wilayah Yasrib.

Jelaslah bahwa, tipe masyarakat demikian memerlukan penataan

${ }^{17}$ Miriam Budiarjo, Dasar-Dasar Ilmu Politik, PT Gramedia, Jakarta, 1989, h.32. Ibn Khaldun. Muqaddimat, Dar al-Fikr, t.t., h 41; dan Abu Hamid al-Ghazali, Ihya' 'Ulum al-Din, Dar al-Fikr, Beirut, 1975, h. 1745. Para pemikir muslim klasik ini juga berpendapat bahwa manusia di samping memiliki watak cenderung bersaing juga suka bekerja sama dalam mewujudkan kebutuhannya.

${ }^{18}$ Soejono Soekanto, Sosiologi Suatu Pengantar, CV Rajawali, Jakarta, 1982, h.94.

${ }^{19}$ Zainal Abidin Ahmad, op.cit., h. 56 
dan pengendalian etika sosial secara bijak dengan membuat undang-undang dan peraturan yang dapat menciptakan rasa aman dan keadaan damai atas dasar keserasian dan keadilan dan dapat diterima oleh semua golongan. Penataan dan pengendalian etika dapat dilakukan oleh seseorang terhadap kelompok lain, atau suatu kelompok terhadap lain. Para pemikir muslim, Ibn Abi Rabi, al-Mawardi, al-Gazali, dan Ibn Khaldun, juga berpendapat bahwa untuk mewujudkan masyarakat etika diperlukan terciptanya rasa aman, keadaan damai, keadilan yang menyeluruh, undang-undang dan siasat yang berkaitan dengan pengaturan kerja sama antara kelompok-kelompok masyarakat untuk menjamin kepentingan bersama, serta pemimpin yang berwibawa untuk melaksanakannya.

Nabi Muhammad saw. tampaknya memahami benar bahwa masyarakat yang beliau hadapi adalah masyarakat majemuk yang masing-masing golongan bersikap bermusuhan terhadap golongan lain. Untuk itu, beliau melihat perlu adanya etika untuk mengatur hubungan-hubungan antar golongan dalam kehidupan sosial, ekonomi, politik, dan agama. Estimasi (pernyataan) ini didasarkan pada langkah beliau setelah tiba di Madinah.

Langkah pertama, begitu beliau tiba di kota itu, adalah membangun masjid. Lembaga keagamaan, sosial dan etika dari segi agama berfungsi sebagai tempat beribadah kepada Allah swt, dan dari segi sosial berfungsi sebagai tempat mempererat hubungan dan ikatan di antara anggota jamaah Islam. Langkah beliau yang kedua ialah menciptakan etika persaudaraan nyata yang efektif antara orang-orang Islam Mekah dan Madinah, yaitu setiap dua orang bersaudara karena Allah. Misalnya Abu Bakar bersaudara dengan Kharijat bin Zuhair, 'Umar bin Khathtab bersaudara dengan'Itban bin Malik al-Khazraj, 'Abd al-Rahman bin 'Auf bersaudara dengan Sa'ad bin Rabi' dan seterusnya. Etika ini dimaksudkan untuk mempererat persatuan di antara sesama kaum muslimin dan untuk menghilangkan permusuhan lama di kalangan mereka.

Etika tersebut bukan diikat oleh hubungan kabilah, melainkan ikatan atas dasar akidah dan agama. Hal ini sejalan dengan sikap kaum muslimin Madinah dalam Bai'at 'Aqabat Pertama dan Kedua, bahwa mereka telah melepaskan hubungan mereka dengan kabilah mereka dan mereka bersatu dalam agama yang dibawa oleh Nabi Muhammad saw. Etika yang dibentuk 
oleh Nabi itu merupakan awal terbentuknya umat Islam untuk pertama kali. Hitti menggambarkannya sebagai "suatu miniatur dunia Islam".

Jika langkah pertama dan kedua ditujukan khusus kepada konsolidasi umat Islam, maka langkah beliau berikutnya ditujukan kepada seluruh penduduk Madinah. Untuk ini beliau membuat perjanjian tertulis atau Piagam yang menekankan pada persatuan yang erat di kalangan kaum muslimin dan kaum Yahudi, menjamin kebebasan beragama bagi semua golongan, menekankan akerja sama dan persamaan hak dan kewajiban semua golongan dalam kehidupan sosial politik dalam mewujudkan pertahanan dan perdamaian, dan menetapkan wewenang bagi Nabi untuk menengahi dan memutuskan segala perbedaan pendapat dan perselisihan yang timbul di antara mereka. Negara baru yang bernama Madinah ternyata membawa kedamaian dan kebahagiaan bagi semua komunitas di sana, baik komunitas Muslim, Yahudi, Kristen maupun suku-suku atau kelompok lainnya - sesuatu yang telah lama mereka nanti-nantikan.

Langkah-langkah Nabi tersebut, menurut Watt, telah menciptakan situasi baru dengan menghilangkan atau memperkecil pertentangan-pertentangan di antara suku-suku. Situasi ini pula yang diinginkan oleh penduduk Madinah, khususnya golongan Arab, sehingga Nabi Muhammad adalah orang yang dapat diterima, akseptabel oleh mereka. ${ }^{20}$ Harapan ini ter-cemin dalam ikrar mereka dalam Baiat 'Aqabat Pertama dan Kedua yang mengakui Muhammad sebagai Nabi dan pemimpin mereka, dan meng-harapkan peranannya untuk mempersatukan penduduk Madinah sehingga mereka memberi jalan kepada beliau agar bersedia hijrah ke lingkungan mereka.

Keberhasilan Nabi tersebut membuat posisi beliau sangat berbeda dari ketika di Mekah, sekalipun beliau telah berdakwah selama kurang lebih 13 tahun di kota kelahirannya itu, namun beliau belum berhasil membentuk komunitas Islam yang bebas dan merdeka, karena posisinya pada waktu itu sangat lemah dan tidak mempunyai kekuatan politik untuk itu. Tapi, setelah di Madinah keadaannya berubah. Beliau berhasil membentuk masyarakat Islam yang bebas dan merdeka bersama komunitas lain, non-muslim, yang juga merupakan satu kesatuan dengan umat Islam, untuk bekerja sama dalam berbagai aspek kehidupan.

${ }^{20} \mathrm{Ibid}$. 
Demikianlah bahwa etika Islam menampakkan diri dalam berbagai manifestasi penting dan yang terbaik adalah dalam ajaran-ajarannya. Rangkaian ajaran yang meliputi berbagai bidang, seperti hukum agama (fikih), keimanan (tauhid), etika (akhlaq, seringkali disempitkan oleh masyarakat hingga menjadi hanya kesusilaan belaka) dan sikap hidup, menampilkan kepedulian yang sangat besar kepada unsur-unsur utama dari kemanusiaan (al-insaniyah).

Prinsip-prinsip etika sosial seperti persamaan derajat di muka hukum, perlindungan warga masyarakat dari kedzaliman dan kesewenang-wenangan, penjagaan hak-hak mereka yang lemah dan menderita kekurangan dan pembatasan atas wewenang para pemegang kekuasaan, semuanya jelas menunjukkan kepedulian di atas. Sementara itu, etika yang tercemin dalam ajaran-ajaran yang memiliki kepedulian kepada unsur-unsur utama kemanusiaan itu diimbangi pula oleh kearifan yang muncul dari keterbukaan yang membuat kaum Muslim selama sekian abad menyerap segala macam manifestasi kultural yang datang dari pihak peradaban-peradaban lain, baik yang masih ada waktu itu maupun yang sudah meng-alami penyusutan luar biasa (seperti peradaban Persia).

Kearifan yang muncul dari proses saling pengaruh-mempengaruhi antara peradaban-peradaban yang dikenal waktu itu di kawasan "Dunia Islam" waktu itu, yang kemudian mengangkat peradaban Islam ke tingkat sangat tinggi, hingga menjadi apa yang disebutkan oleh sejarawan agung Arnold J. Toynbee, adalah salah satu di antara enam belas oikumene yang menguasai dunia. Kearifan dari oikumene Islam itulah yang paling tepat untuk disebut sebagai kosmopolitanisme peradaban Islam.

\section{Penutup}

Masyarakat Madani adalah masyarakat yang menerapkan secara empiris prinsip normatif Islam tentang egalitarianisme, demokrasi, partisipasi dan keadilan sosial. Masyarakat ini telah menyajikan kepada umat manusia, sebuah gambaran tatanan sosial politik yang telah mengenal kehidupan berkonstitusi, di bawah naungan konstitusi yang dikenal dengan sebutan Mitsaq al-Madinah (Piagam Madinah).

Adapun dasar-dasar masyarakat Madani adalah: Pertama, pembangunan masjid. Selain untuk tempat salat, masjid juga sebagai sarana penting 
untuk mempersatukan dan mempertalikan jiwa mereka, di samping sebagai tempat bermusyawarah merundingkan masalah-masalah yang dihadapi. Masjid pada masa Nabi Muhammad saw. bahkan juga berfungsi sebagai pusat pemerintahan.

Dasar kedua, adalah ukhuwah Islamiyyah, persaudaraan sesama muslim. Nabi mempersaudarakan antara golongan Muhajirin dan Anshar. Dengan demikian, diharapkan setiap muslim merasa terikat dalam suatu persaudaraan dan kekeluargaan. Apa yang dilakukan Rasulullah ini berarti menciptakan suatu bentuk persaudaraan berdasarkan agama, menggantikan persaudaraan berdasarkan keturunan darah.

Dasar ketiga, hubungan persahabatan dengan pihak-pihak lain yang tidak beragama Islam. Di Madinah di samping orang-orang Arab Islam, juga terdapat golongan masyarakat Yahudi dan orang-orang Arab yang masih menganut agama nenek moyang mereka. Agar stabilitas masyarakat dapat diwujudkan, Nabi Muhammad mengadakan ikatan perjanjian dengan mereka. Sebuah piagam yang menjamin kebebasan beragama orangorang Yahudi. Setiap golongan masyarakat memiliki hak tertentu dalam bidang sosial dan keagamaan. Kemerdekaan beragama dijamin, dan seluruh anggota masyarakat berkewajiban mempertahankan keamanan negeri itu dari serangan luar.

Etika Islam menampakkan diri dalam berbagai manifestasi penting dan yang terbaik adalah dalam aktifitas kehidupan sehari-hari masyarakat Madinah. Rangkaian ajaran yang meliputi berbagai bidang, seperti hukum agama (fikih), keimanan (tauhid), etika (akhlaq, seringkali disempitkan oleh masyarakat hingga menjadi hanya kesusilaan saja) dan sikap hidup.

Salah satu ajaran yang dengan sempurna menampilkan etika Islam adalah lima buah jaminan dasar, yaitu jaminan akan dasar: (1) keselamatan fisik warga masyarakat dari tindakan badani diluar ketentuan hukum, (2) keselamatan keyakinan agama masing-masing, tanpa ada paksaan untuk berpindah agama, (3) keselamatan keluarga dan keturunan, (4) keselamatan harta benda dan milik pribadi diluar prosedur hukum, dan (5) keselamatan propesi.

Dari uraian singkat di atas terlihat bahwa etika yang tercermin dalam masyarakat Madani bukanlah etika dalam pengertian akhlaq ataupun moral semata-mata, tetapi lebih luas dan mendasar dari pada itu. Jika 
disarikan, etika yang tumbuh dan berkembang dalam masyarakat Madani mempunyai pengertian sebagai ajaran yang mengajarkan dan menuntun manusia kepada tingkah laku yang baik berdasarkan ajaran Allah (Alquran) dan Rasul-Nya (Sunnah), bersifat universal dan komprehensif dan dapat diterima oleh seluruh umat manusia di segala waktu dan tempat. Akhirnya penulis berpendapat bahwa jika umat Islam mempraktekkan etika Islam seperti yang dicontohkan Nabi Muhammad saw. pada masyarakat Madinah, maka umat Islam di mana saja akan dapat meraih kehidupan yang sejahtera, adil dan makmur sebagaimana adanya masyarakat Madani. 


\section{DAFTAR PUSTAKA}

Abdul Aziz Thaha, Islam dan Negara dalam Politik Orde Baru, Gema Insani Press, Jakarta, 1996.

Abu Hamid al-Ghazali, Ihya' 'Ulum al- Din, Dar al-Fikr, Beirut, 1975.

Adi Suryadi Culla, Masyarakat Madani, RajaGrafindo Persada, Jakarta, 1999

Aswab Mahasin et.al. (ed), Ruh Islam dalam Budaya Bangsa: Wacana antar Agama dan Bangsa, Yayasan Festival Istiqlal, Jakarta, 1996.

Ernest Gellner, Membangun Masyarakat Sipil: Prasyarat Menuju Kebebasan, Mizan, Bandung, 1995

Ibn Khaldun. Muqaddimat, Dar al-Fikr, t.t.

Mansur Fakih, Masyarakat Sipil untuk Transformasi Sosial: Pergolakan Ideologi di Dunia LSM Indonesia, Pustaka Pelajar, Yogyakarta, 1996

Miriam Budiarjo, Dasar-Dasar Ilmu Politik, PT Gramedia, Jakarta, 1989

Muhammad Khalid, Khatam al-Nabiyyin, al-Qahirat, t. th.

Naquib Al-Attas, "Masyarakat Madani: Wajah Indonesia tahun 2020", Harian Republika, 15 September 1998

Nurcholish Madjid, "Menuju Masyarakat Madani” dalam Ulumul Qur'an. No. 2 /vii/1996

Nurcholish Madjid, Cita-cita Politik Islam Era Reformasi, Paramadina, Jakarta, 1999

Soejono Soekanto, Sosiologi Suatu Pengantar, CV Rajawali, Jakarta, 1982.

Zainal Abidin Ahmad, Piagam Nabi Muhammad Saw. Konstitusi Negara Tertulis yang Pertama di Dunia, Bulan Bintang, Jakarta, 1973 